\title{
Influence of rearing-water temperature on life stages' vector attributes, distribution and utilisation of metabolic reserves in Culex quinquefasciatus (Diptera: Culicidae): implications for disease transmission and vector control
}

\author{
Azubuike Christian Ukubuiwe ${ }^{1 *}$ D, Israel Kayode Olayemi ${ }^{1}$, Francis Ofurum Arimoro², \\ Innocent Chukwuemeka James Omalu ${ }^{3}$, Bulus Musa Baba ${ }^{4}$, Chinenye Catherine Ukubuiwe ${ }^{5}$, \\ Moses Olusesan Odeyemi ${ }^{1}$ and Kamoru Abdulazeez Adeniyi ${ }^{1}$
}

\begin{abstract}
Background: This study aims at determining the effects of rearing water temperature on immature development, adult vectorial attributes and teneral accumulation in Culex quinquefasciatus (CX. quinquefasciatus) mosquitoes. Immature life stages of the species were reared (to adulthood) in water media with temperature regimens of 28, 30, 32 and $34{ }^{\circ} \mathrm{C}$ generated and maintained by digital electrical thermostats. Immature and adult vectorial attributes (i.e. duration of development, growth rates, immature and adult survivorship, emergence rates and adult longevity), and rates of accumulation, distribution and utilisation (for pupation and eclosion) of teneral reserve (lipid, glucose, glycogen and protein) by life stages of the species were determined.

Result: Results revealed significant negative effects of temperature increase on all parameters measured. Among these, only rate of larval growth (range $=0.0589 \pm 0.0017$ to $0.0930 \pm 0.0003 \mathrm{mg} /$ day) increased with temperature rise; others reduced with rise in temperature. Total immature duration ( $9.75 \pm 0.09$ to $6.43 \pm 0.11$ days), immature survivorship ( $94.01 \pm 0.18$ to $73.26 \pm 3.72 \%)$, total emergent adults ( $72.00 \pm 2.14$ to $14.50 \pm 2.67$ adults/100 larvae), percentage of emergence, adult daily survivorship (76.86 \pm 1.87 to $63.66 \pm 0.18 \%)$ and post-emergence longevity (23.91 \pm 2.97 to $16.90 \pm 1.97$ days) reduced with increase in temperature. Accumulation of teneral components increased across larval instars, but decreased with temperature rise and at metamorphosis (pupation and eclosion). Immature composition for lipid, glucose, glycogen and protein ranged, respectively, from $9.79 \pm 1.05$ to $20.07 \pm 0.33,8.49 \pm 0.44$ to $14.33 \pm 0.44,28.19 \pm 2.34$ to $42.87 \pm 0.12$ and $24.11 \pm 0.71$ to $35.55 \pm 0.15 \mu \mathrm{g} /$ mosquito. While, adult values for these ranged from $7.53 \pm 0.40$ to $20.66 \pm 0.61,7.45 \pm 0.87$ to $13.86 \pm 0.83,22.63 \pm 0.85$ to $33.64 \pm 0.79$, and $17.81 \pm 1.02$ to 31 . $45 \pm 1.40 \mathrm{\mu g} /$ mosquito, respectively. Glycogen and protein had the highest rates of accumulation, while metabolic reserves utilised for pupation and eclosion varied significantly with temperature change.

(Continued on next page)
\end{abstract}

\footnotetext{
* Correspondence: a.ukubuiwe@futminna.edu.ng

${ }^{1}$ Department of Animal Biology, Applied Entomology Unit, Federal University

of Technology, Minna, Nigeria

Full list of author information is available at the end of the article
} 


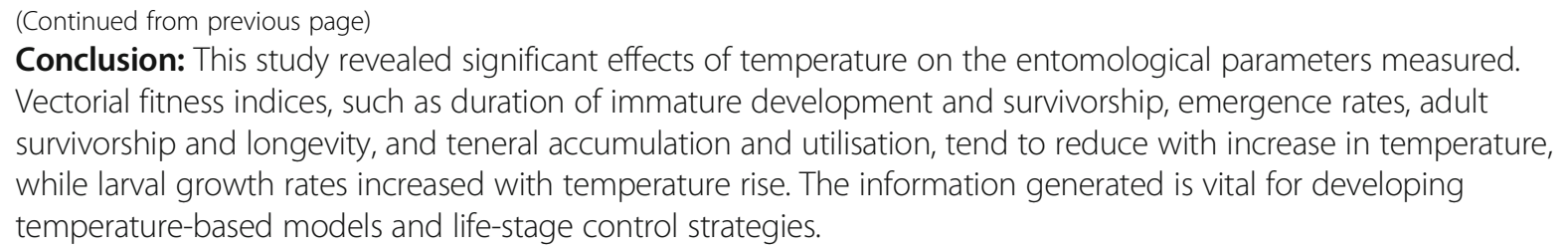

Keywords: Teneral reserve, Metabolic reserve, Larval growth, Emergence ratio

\section{Background}

Temperature is a very important abiotic factor that affects the development of immature stages of insects (Al-Saffar, Grainger, and Aldrich, 1995), and especially mosquitoes (Alto and Juliano, 2001). This is, especially, so because the basal temperatures of these organisms are closely dependent on ambient temperature (Carrington, Armijos, Lambrechts, Barker, and Scott, 2013).

For ectotherms, temperature is, probably, the most important physical quantity that regulates juvenile development and adult success rates (Atkinson, 1995), immature growth rates and morphometrics (Ukubuiwe and Olayemi, 2014), and population dynamics of immature and adult mosquitoes (Phasomkusolsil et al. 2011). In aquatic insects (e.g. immature mosquitoes), where all pre-imaginal life stages are spent in water, developmental successes (duration of development and survivorship) is a product of diverse physiological interactions between temperature and other temperature-dependent vital life processes. More so, the quality of adult life of such insects is dependent on the outcomes of these relationships (Mpho, Callaghan, and Holloway, 2002a).

Generally, in insects, optimum ranges of temperatures exist and are required for successful pre-imaginal development (Loetti, Nora, Paula, and Schweigmann, 2008). This is to ensure integrity of enzymes and protein structures (Bowler, 1987), completion of critical metabolic reactions (Oda et al., 2002) and avoidance of build-up of thermal stress (Carrington et al. 2013). These temperature ranges are usually species- (Loetti, Nicolás, and Burronia, 2011) and life-stage specific (Olayemi, Onumanyi, Ukubuiwe, and Jibrin, 2016).

Pre-imaginal duration of development and survivorship, and adult life trait attributes, such as number at emergence, daily survivorship and longevity is critical in determining vectorial fitness, competence, and capacity of mosquito vectors, and the dynamics of disease transmission. For example, decreased immature developmental time coupled with higher immature survivorship ensures higher adult emergence, with the resultant surge in adult population (Nasci, Berry, Restifo, and Moore, 1996). More so, higher numbers of emerged adults guarantee greater success at finding mates (Workman and Walton, 2000) and increased host-vector contacts (Randell, Dickinson, Shayo, Mboera, and Kramer, 2010). Meanwhile, higher daily survivorship and longer post-emergence longevity has been correlated with higher cyclical transmission of disease by vectors (Strickman and Kittayapong, 2003).

Further, temperature primarily influences the accumulation, distribution and allocation of larval metabolic resources in insects (Bochdanovits and De Jong, 2003). These have resultant effects on adult fitness parameters such as wing lengths (Lanciani and Le, 1995), fluctuating asymmetry (Markow, 1995; Parsons, 1990) and adult size (Sibly and Atkinson, 1994). Temperature also affects longevity and fecundity (Armbruster and Hutchinson, 2002; Joshi, 1996), and increases the chances of susceptibility to pathogens (Mourya, Yadav, and Mishra, 2004).

According to Briegel (1990a), the physiological fitness of an adult mosquito is dependent on teneral reserve accumulation, distribution and utilisation during pre-imaginal development. These reserves (lipid, glycogen, glucose and protein) are crucial for most adult life traits such as survivorship, flight, vitellogenesis and longevity (Briegel, 1990b). Accumulation of these reserves during phagoperiods (i.e. larval instars I-IV), their distribution and utilisation across immature instars and life stages for life processes is dependent on the interplay of several factors, such as levels of environmental stress (Mpho et al. 2002a).

In the present study, we investigated the influence of thermal stress on immature developmental indices, adult vectorial attributes, as well as, accumulation, distribution and utilisation of teneral reserves in Culex quinquefasciatus; a medically important vector species. This is necessitated to understand and increase knowledge-base of the influence of breeding water temperature on growth, development and vector competence of mosquitoes and for the development of cost-effective, integrated and eco-friendly mosquito-vector control protocols.

\section{Methods}

\section{Preparation of water temperature regimen}

Rearing-water media with temperature regimens of 28.00 , $30.00,32.00$ and $34.00{ }^{\circ} \mathrm{C}$ were generated and regulated using digital electrical thermostats (model: $300 \mathrm{~W}$, LifeTech Aquarium $^{\circ}$ GB4706.67-2003) according to methods described by Olayemi et al. (2016). The temperature regimen set-ups were in four replicates containing 50 larvae/bowl/ replicate. 
Source and maintenance of experimental mosquito

Freshly laid egg rafts of Culex quinquefasciatus were obtained from the Insectary unit of the Department of Animal Biology, Federal University of Technology, Minna. These were incubated for $24 \mathrm{~h}$ to ensure complete hatching. The hatched-out larvae were reared following standard techniques in plastic trays $(30 \mathrm{~cm} \times 25 \mathrm{~cm} \times$ $5 \mathrm{~cm}$ ), at the rate of 50 larvae/bowl of distilled water. The larvae were fed Coppens ${ }^{\bullet}$ (fish feed), at the rate of $0.32 \mathrm{mg} / 100$ larvae every other day, sprinkled on the water surface (Ukubuiwe, Olayemi, Omalu, Jibrin, and Oyibo-Usman, 2013). On every alternate day, the water from the culture bowls were changed, this would continue until pupal stage. The pupae were separated daily and placed in plastic bowl half-filled with thermostatregulated-water until emergence. Adult mosquitoes that were unable to emerge or break free from the pupal case were considered dead. The emerged adults were put in adult-holding cages and fed with $10 \%$ sucrose solution. Total number of emergent (sum of male and female adult), daily survivorship and post-emergence longevity was noted daily (Ukubuiwe, Olayemi, and Jibrin, 2016).

\section{Determination of entomological parameters Developmental indices}

Development indices adopted in this study were duration of development and survivorship of immature instars and stages.

\section{Duration of development of immature stages}

This was determined as according to the methods of Ukubuiwe et al. (2016). Briefly, the mosquitoes were monitored twice (0600 and $1800 \mathrm{~h}$ daily) to determine the numbers of immature life stage that changed to the next stage of development. This was recorded on daily basis till pupation and emergence. The duration of development of immature stage represents the time a particular immature life stage spends before transforming to the next stage of development. These were determined for the larval instars I-IV, (LI-IV), and pupal stage. The total larval and immature duration were determined as the sum of duration of the four larval instars and all immature stages (LI-IV and pupa), respectively. These values were expressed in days and estimated using the following formula:

$$
D_{i}=T_{i}-\left(t_{i-1}\right)
$$

Where, $D_{\mathrm{i}}=$ duration of a life stage in days; $T_{\mathrm{i}}=$ present mean age; $t_{\mathrm{i}-1}=$ previous mean age at moulting.

\section{Survivorship of immature stages}

Survival rates during immature life stages were determined as the proportion of mosquitoes at the beginning of a life stage that successfully entered the next stage. It was determined for larval instars and pupal stage, and expressed as percentages and computed using the formula:

$$
S_{i}=\frac{n_{i}}{n_{i-1}} \times 100
$$

Where $S_{i}$ is the survival rates in instar stage $i$ in percentage; $n_{i}$ is the number of larvae entering instar stage $i$, and $n_{i-1}$ be the number of larva that entered the preceding instar stage.

\section{Determination of number of adults at eclosion, emergence sex ratio, daily survivorship and post-emergence longevity of adults}

The number of adults at eclosion was determined by counting adult male and female mosquitoes at eclosion. Emergence ratio was determined by recording the sex and number of adults that emerged (Ukubuiwe et al. 2016). Daily survivorship, expressed in percentage, is a ratio of number of live mosquitoes to dead ones; while longevity, expressed in days, was estimated as the number of days adult (male and female) spent post-emergence, while fed with only sugar solution (10\%) soaked in cotton wool (Olayemi and Ande, 2009.

\section{Adult fitness attributes}

Indices of adult fitness were determined from wing length (WL) and fluctuating asymmetry (FA). Studies have shown that the wings of insects do not grow after eclosion; hence, their lengths are constant and give a measure of body size. More so, fluctuating asymmetry measures the degree of variations between the lengths of the right and left wings, and is a proxy for ontogenic stress, and hence fitness. For WL $(\mathrm{mm})$ determination, the wings were carefully detached from the thorax of emerged adult mosquitoes, with the aid of entomological pins; and measured as the distance between the base of the costa and distal extremity of the R3 vein, excluding the fringe setae (Loetti et al. 2011). Wing FA $(\mathrm{mm})$ was expressed as a difference between the lengths of left and right wings (Ukubuiwe et al. 2016).

\section{Teneral reserve accumulation}

The quantities of teneral reserve (lipid, glycogen, glucose and protein) accumulated at each life stage was estimated according to methods described by Van-Handel (1985a, 1985b), Van-Handel and Day (1988) and Kaufmann and Brown (2008). Larval daily rates of accumulation of metabolic reserve (for each teneral component) due to the temperature regimens were obtained by dividing the quantity of the teneral component at LIV by the age at pupation (Timmermann and Briegel, 1993). Metabolic reserve utilised for the processes of pupation and eclosion were also determined, respectively, as the difference in teneral composition between the fourth larval and pupal 


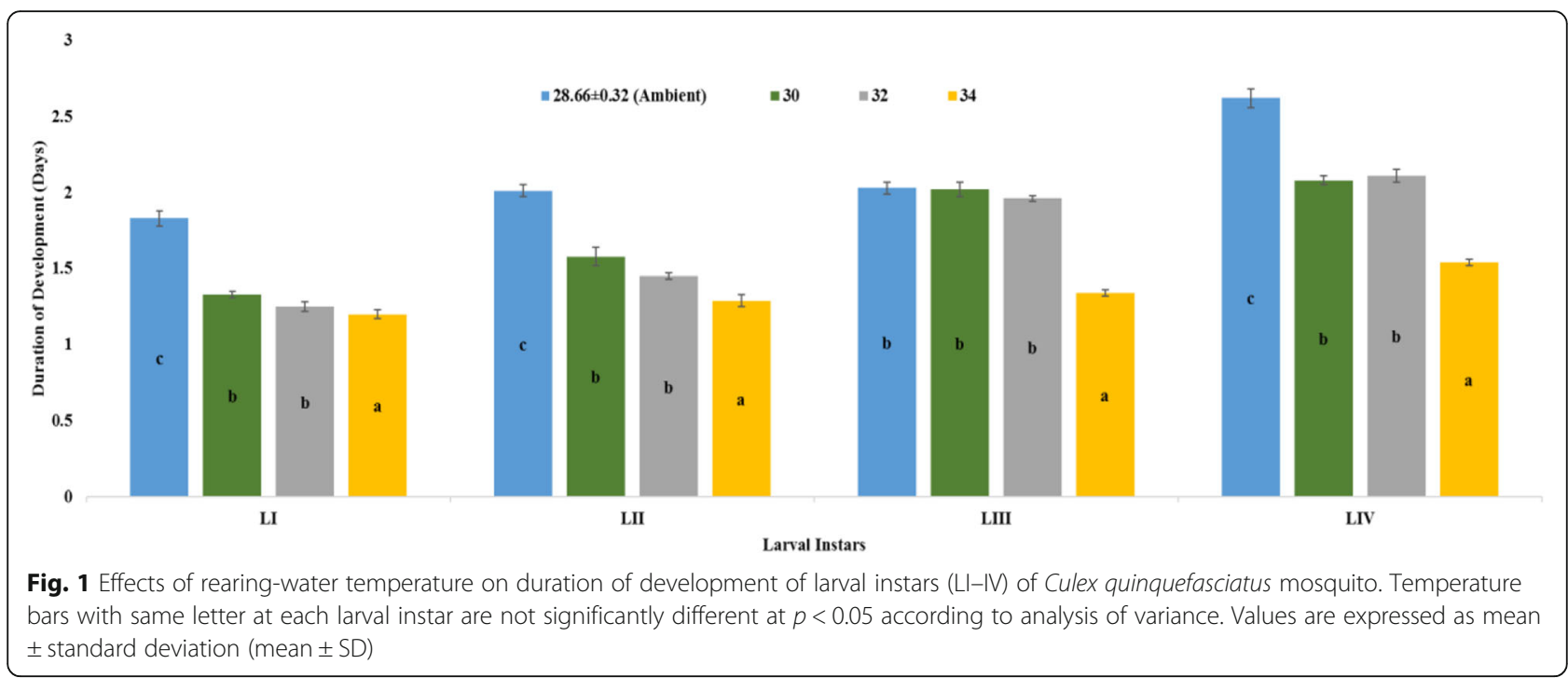

stage, and between the pupal and adult life stages (Ukubuiwe et al. 2017).

\section{Data analysis}

All entomological data generated were tested for goodness-of-fit before analyses. These were processed into means and standard deviation using Microsoft Office Excel 2016 and Statistical Package for Social Scientists (SPSS) Version 21. Differences between means of any two entomologic variables (e.g. between male and female parameters) were compared using Student $t$ test, while those among entomologic variables (e.g. among temperature regimens) were compared for significant difference using one-way and two-ways analysis of variance (ANOVA), as appropriate. All decisions on statistical comparison of means was taken at $p=0.05$ level of significance. Duncan multiple range test (DMRT) separated differences between means.

\section{Results}

Effects of rearing-water temperature on duration of development and larval growth rates of Culex quinquefasciatus mosquito

Analyses revealed significant $(p<0.05)$ effects of temperature on duration of development of all immature life stages and larval instars, and on larval growth rate of the species (Fig. 1 and Table 1). There was significant reduction in duration of development as temperature increased from $28.66 \pm 0.32$ to $34.00{ }^{\circ} \mathrm{C}$. While mosquito larval instars reared at the later temperature regimen elicited the shortest development times, those reared in the former had the longest (Fig. 1).

The varied development times of the larval instars resulted to variations in total larval duration times, with the larvae reared at $34.00{ }^{\circ} \mathrm{C}$ having the shortest $(5.38 \pm 0.13)$ while those reared at ambient, the longest (8.94 \pm 0.24 days). There was no significant difference in developmental times at 30.00 and $32.00{ }^{\circ} \mathrm{C}$. Duration of pupal and immature duration of development followed the same trend as the larval instars development times (Table 1).

Growth rates of the larvae exhibited a positive relationship with increase in temperature: the highest temperature tested $\left(34.00{ }^{\circ} \mathrm{C}\right)$, elicited the fastest growth rate while ambient temperature, the slowest (Table 1).

\section{Effects of rearing-water temperature on survivorship of immature Culex quinquefasciatus mosquito}

Analyses revealed significant reduction in immature survivorship as temperature increased from $28.66 \pm 0.32$ to

Table 1 Effects of rearing-water temperature on duration of development and larval growth rate of Culex quinquefasciatus mosquito

\begin{tabular}{lllll}
\hline Temperature $\left(^{\circ} \mathrm{C}\right)$ & \multicolumn{2}{c}{ Duration of development (days) } & Larval growth \\
\cline { 2 - 4 } & Total larval & Pupal & Total immature & rate (mg/day) \\
\hline $28.66 \pm 0.32$ (ambient) & $8.49 \pm 0.24^{\mathrm{c} *}$ & $1.26 \pm 0.15^{\mathrm{c}}$ & $9.75 \pm 0.09^{\mathrm{d}}$ & $0.0589 \pm 0.0017^{\mathrm{a}}$ \\
30.00 & $7.02 \pm 0.15^{\mathrm{b}}$ & $1.05 \pm 0.13^{\mathrm{b}}$ & $7.98 \pm 0.14^{\mathrm{c}}$ & $0.0713 \pm 0.0016^{\mathrm{b}}$ \\
32.00 & $6.78 \pm 0.12^{\mathrm{b}}$ & $0.96 \pm 0.02^{\mathrm{ab}}$ & $7.62 \pm 0.19^{\mathrm{b}}$ & $0.0737 \pm 0.0013^{\mathrm{c}}$ \\
34.00 & $5.38 \pm 0.12^{\mathrm{a}}$ & $0.84 \pm 0.07^{\mathrm{a}}$ & $6.43 \pm 0.11^{\mathrm{a}}$ & $0.0930 \pm 0.0003^{\mathrm{d}}$
\end{tabular}

*Within a column, means $( \pm$ SD) followed by same letter are not significantly different at $p<0.05$ according to Duncan multiple range test following analysis of variance (ANOVA) 


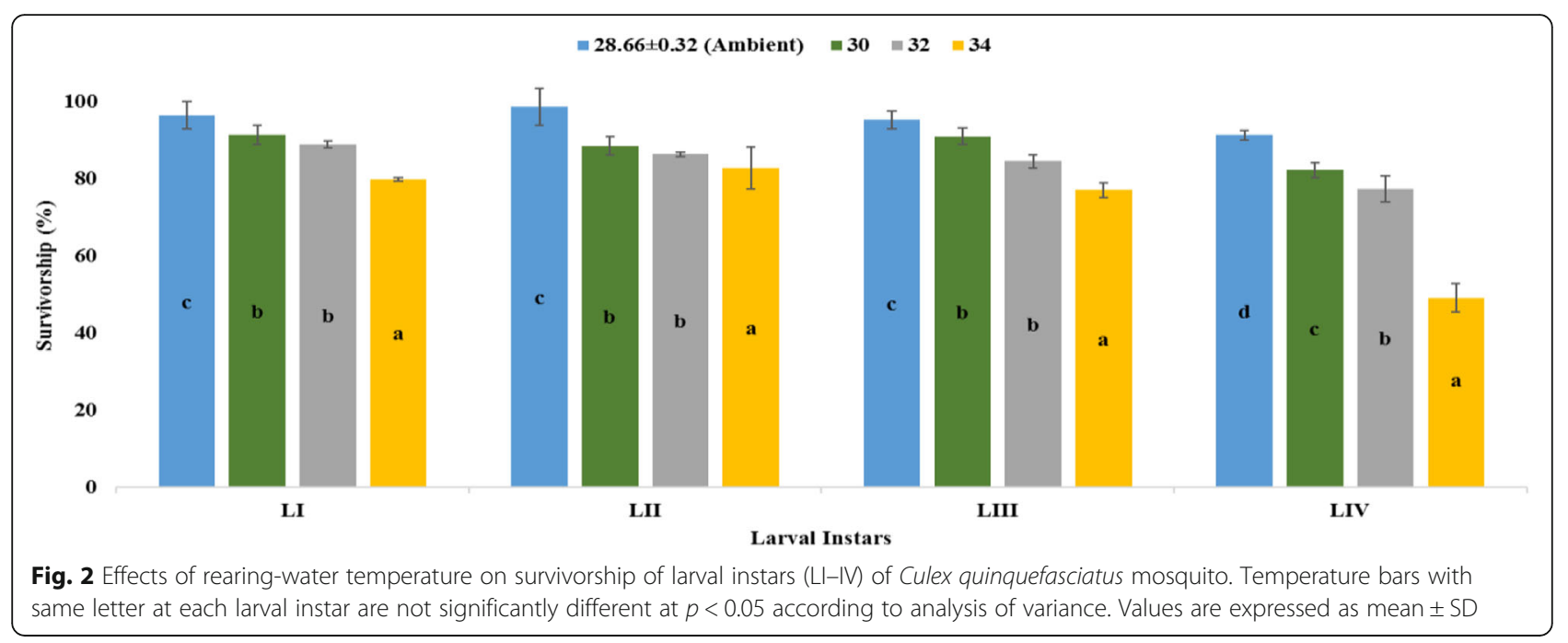

$34.00{ }^{\circ} \mathrm{C}$ (Fig. 2 and Table 2). Unlike duration of development, survivorship of larval instars (I-IV) was negatively affected by increase in temperature (Fig. 2). Similar trends were observed for survivorship at pupal stage and in average immature survivorship (Table 2).

Effects of rearing-water temperature on emergence, postemergence longevity and survivorship of adult Culex quinquefasciatus mosquito

Figures $3 \mathrm{a}-\mathrm{c}$ shows the effects of temperature on emergence, survivorship and post-emergence longevity of adult $C x$ quinquefasciatus. Analyses revealed significant reduction in the total numbers of emergent adult mosquitoes as temperature increased from $28.66 \pm 0.32$ to $34.00{ }^{\circ} \mathrm{C}$. The number of emerged male $\left({ }^{\top}\right)$ and female (ㅇ) also differed significantly in the same trend (Fig. 3a). There were, significantly, greater numbers of female (44.50 \pm 1.60 adult/100 larvae) than male $(27.50 \pm 3.74$ adult/100 larvae) of the species at all temperature tested.

Post-emergence longevity (PEL) of the species differed, significantly, among the temperature regimens. There was an initial increase in PEL as temperature increased from $28.66 \pm 0.32(19.36 \pm 1.58$ days $)$ to $30.00{ }^{\circ} \mathrm{C}(23.91$

Table 2 Effects of rearing-water temperature on survivorship of immature Culex quinquefasciatus mosquito

\begin{tabular}{llll}
\hline $\begin{array}{l}\text { Temperature } \\
\left({ }^{\circ} \mathrm{C}\right)\end{array}$ & \multicolumn{3}{l}{ Survivorship $(\%)$} \\
\cline { 2 - 4 } & Average larval & Pupal stage & Average immature \\
\hline $28.66 \pm 0.32$ & $93.01 \pm 0.05^{\mathrm{c}^{*}}$ & $97.98 \pm 0.69^{\mathrm{b}}$ & $94.01 \pm 0.18^{\mathrm{b}}$ \\
30.00 & $86.85 \pm 1.78^{\mathrm{b}}$ & $98.08 \pm 1.93^{\mathrm{b}}$ & $89.09 \pm 1.81^{\mathrm{b}}$ \\
32.00 & $86.16 \pm 0.86^{\mathrm{b}}$ & $96.45 \pm 0.16^{\mathrm{b}}$ & $88.22 \pm 0.72^{\mathrm{b}}$ \\
34.00 & $73.57 \pm 1.05^{\mathrm{a}}$ & $71.81 \pm 13.19^{\mathrm{a}}$ & $73.26 \pm 3.72^{\mathrm{a}}$ \\
\hline
\end{tabular}

*Within a column, means ( \pm SD) followed by same letter are not significantly different at $p<0.05$ according to Duncan multiple range test following analysis of variance (ANOVA) \pm 2.97 days), with subsequent reduction with further increase in temperature. PEL also varied among the adult sexes of the species within and among temperature regimens (Fig. 3b).

Mean daily survivorship of adult $C x$. quinquefasciatus also reduced, significantly, with increase in temperature treatments. However, there was no significant $(p>0.05)$ difference between survivorship between sexes within a temperature regimen; it ranged from $63.66 \pm 0.18$ (at $34.00{ }^{\circ} \mathrm{C}$ ) to $76.86 \pm 1.87$ (at $28.66 \pm 0.32{ }^{\circ} \mathrm{C}$ ) (Fig. 3c).

\section{Effects of rearing-water temperature on distribution of teneral lipid among life stages of Culex quinquefasciatus mosquito}

Generally, there were significant $(p<0.05)$ increase in the quantities of lipid accumulated as the larvae progressed from first (LI) to fourth (LIV) larval instar, despite increase in temperature. However, within a larval instar (e.g. LI) for all treatments, further increase in temperature above $30.00{ }^{\circ} \mathrm{C}$, significantly, reduced the quantity of lipid accumulated (Fig. 4). More so, as the larval stage progressed to pupal and adult stages, significant reduction in teneral reserve was observed. Average larval, pupal composition, immature and adult lipid accumulation followed similar pattern, i.e. reduction in lipid content as temperature increased (Table 3).

\section{Effects of rearing-water temperature on distribution of teneral glucose among life stages of Culex quinquefasciatus mosquito}

Analyses revealed significant $(p<0.05)$ effects of temperature on life stages' accumulation of glucose. Glucose composition, like lipid, generally, reduced with increase in temperature and during transformation from larvae to pupa and to adult. Hence, adults had the least 

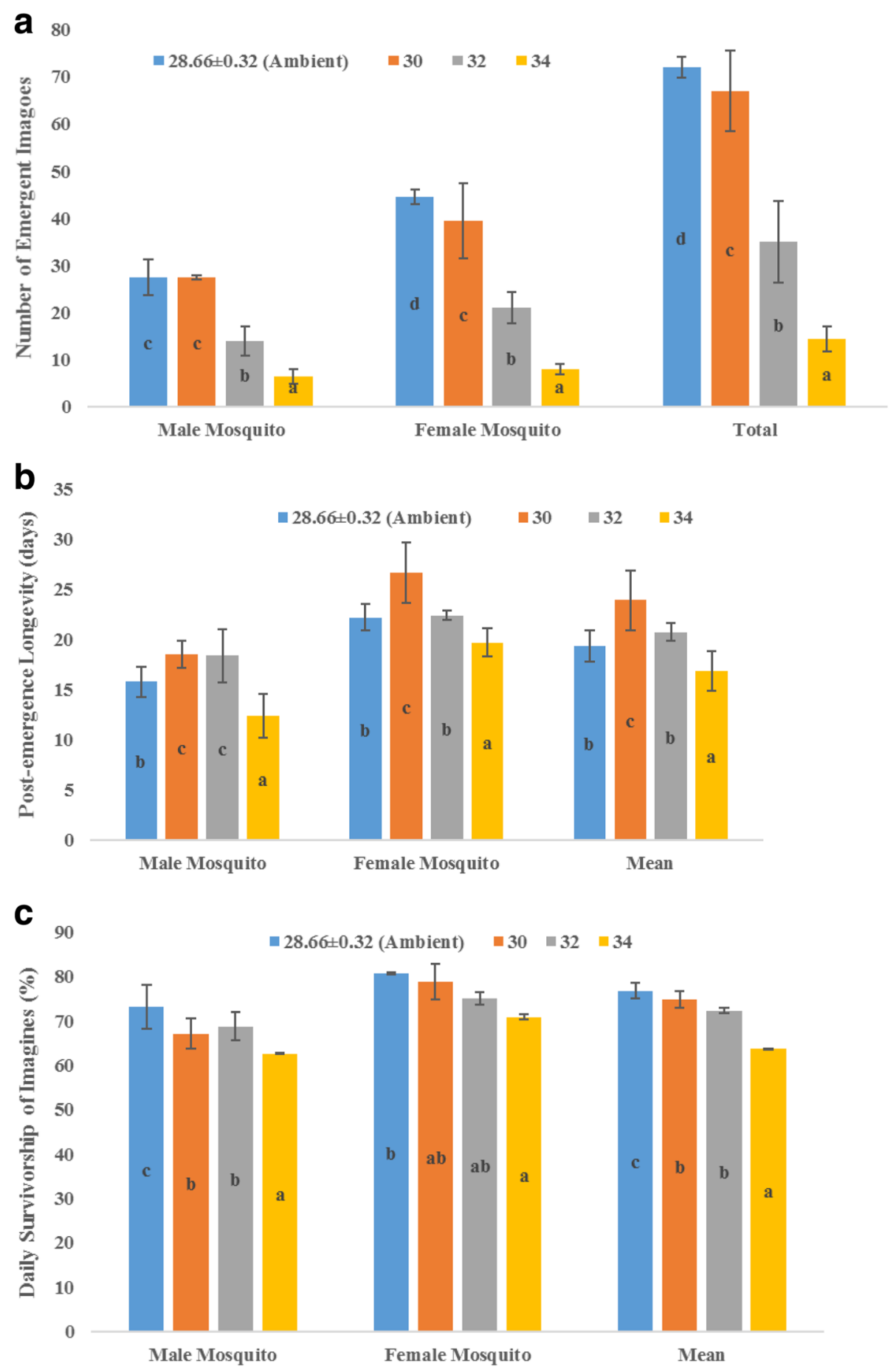

Fig. 3 a Effects of rearing-water temperature on emergence of Culex quinquefasciatus mosquito. Temperature bars with same letter for male, female and total mosquitoes are not significantly different at $p<0.05$ according to analysis of variance. Values are expressed as mean \pm SD. $\mathbf{b}$ Effects of rearing-water temperature on post-emergence longevity of Culex quinquefasciatus mosquito. Adult were sugar-fed only. Temperature bars with same letter for male, female and mean adult mosquito are not significantly different at $p<0.05$ according to analysis of variance. Values are expressed as mean \pm SD. $\mathbf{c}$ Effects of rearing-water temperature on daily survivorship of Culex quinquefasciatus mosquito. Adult were sugar-fed only. Temperature bars with same letter for male, female and mean adult mosquito are not significantly different at $p<0.05$ according to analysis of variance. Values are expressed as mean \pm SD 


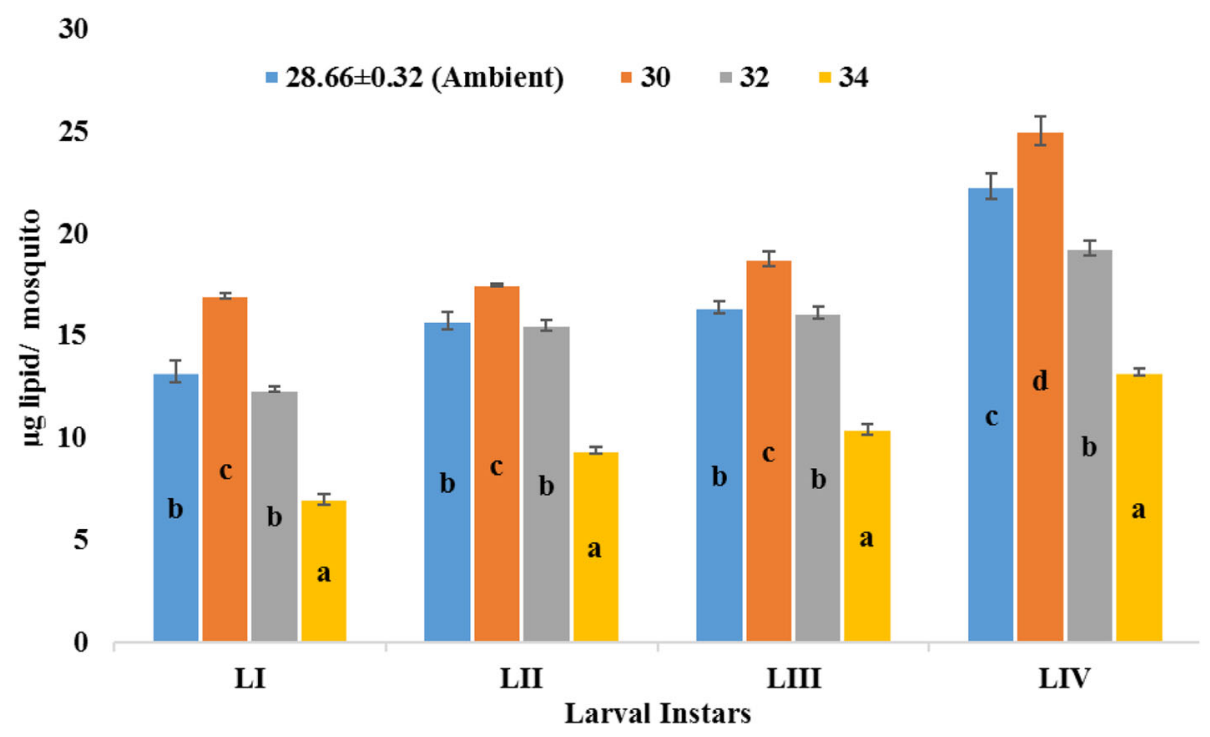

Fig. 4 Effects of rearing-water temperature on teneral lipid accumulation across larval instars (LI-IV) of Culex quinquefasciatus mosquito. Temperature bars with same letter at each larval instar are not significantly different at $p<0.05$ according to analysis of variance. Values are expressed as mean \pm SD

values. Larval instars reared at $30.00{ }^{\circ} \mathrm{C}$ had the highest teneral glucose.

Composition of larval instars ranged from $5.70 \pm 0.18$ to $9.37 \pm 0.18,7.29 \pm 0.99$ to $12.75 \pm 0.44,9.68 \pm 0.96$ to $15.28 \pm 0.36$ and $10.92 \pm 0.53$ to $17.71 \pm 0.85 \mu \mathrm{g} / \mathrm{mos}$ quito, respectively, at LI, LII, LIII and LIV (Fig. 5). Average larval composition ranged from $8.40 \pm 0.46$ to $13.78 \pm 0.27 \mu \mathrm{g} / \mathrm{mosquito}$, at 34.00 and $30.00{ }^{\circ} \mathrm{C}$, respectively.

The pupal, average immature and adult composition ranged, respectively, from $8.85 \pm 0.58$ to $16.54 \pm 1.10$, $8.49 \pm 0.44$ to $14.33 \pm 0.44$ and $7.45 \pm 0.87$ to $13.86 \pm$ $0.83 \mu \mathrm{g} /$ mosquito, respectively, at 34.00 and $30.00{ }^{\circ} \mathrm{C}$ ) (Table 4).

\section{Effects of rearing-water temperature on distribution of teneral glycogen across life stages of Culex quinquefasciatus mosquito}

Mosquitoes larvae reared at the highest temperature (of $34.00{ }^{\circ} \mathrm{C}$ ) had the lowest values for glycogen content, while those reared at $30.00{ }^{\circ} \mathrm{C}$, the highest (Fig. 6).
Average larval ( $28.19 \pm 2.34$ to $45.06 \pm 0.03 \mu \mathrm{g} /$ mosquito), pupal ( $24.95 \pm 0.71$ to $34.12 \pm 0.51 \mu \mathrm{g} / \mathrm{mosquito}$ ), immature $(28.19 \pm 2.34$ to $42.87 \pm 0.12 \mu \mathrm{g} / \mathrm{mosquito})$ and adult glycogen compositions $(22.63 \pm 0.85$ to $33.64 \pm 0.79 \mu \mathrm{g} /$ mosquito) were significantly $(p<0.05)$ reduced as temperature increased from ambient to $34.00{ }^{\circ} \mathrm{C}$ (Table 5).

\section{Effects of rearing-water temperature on distribution of teneral protein across life stages of Culex quinquefasciatus mosquito}

Analyses revealed significant $(p<0.05)$ effects of rearingwater temperature on protein accumulated in the larval instars (Fig. 7); resulting in variation in average larval composition ranging from $24.70 \pm 0.96$ to $35.93 \pm$ $0.18 \mu \mathrm{g} / \mathrm{mosquito})$. Fourth larval stages of the species had the lowest teneral protein content, irrespective of temperature treatment. More so, the pupal and adult life stages' composition also varied significantly among the temperature regimens. Mosquitoes reared at $34.00{ }^{\circ} \mathrm{C}$ had the least values of protein accumulated (Table 6).

Table 3 Effects of rearing-water temperature on teneral lipid mobilisation across the life stages of Culex quinquefasciatus mosquito

\begin{tabular}{|c|c|c|c|c|}
\hline \multirow[t]{2}{*}{ Temperature $\left({ }^{\circ} \mathrm{C}\right)$} & \multicolumn{4}{|c|}{ Lipid accumulation ( $\mu \mathrm{g} / \mathrm{mosquito})$} \\
\hline & Average larval & Pupal & Average immature & Adult \\
\hline $28.66 \pm 0.32$ & $16.92 \pm 0.16^{c^{*}}$ & $19.01 \pm 0.03^{c}$ & $17.34 \pm 0.14^{c}$ & $15.77 \pm 0.34^{c}$ \\
\hline 30.00 & $19.58 \pm 0.42^{d}$ & $22.02 \pm 0.06^{d}$ & $20.07 \pm 0.33^{d}$ & $20.66 \pm 0.61^{d}$ \\
\hline 32.00 & $15.83 \pm 0.10^{b}$ & $16.99 \pm 0.22^{b}$ & $16.06 \pm 0.11^{b}$ & $14.80 \pm 0.79^{b}$ \\
\hline 34.00 & $10.02 \pm 1.28^{\mathrm{a}}$ & $8.88 \pm 0.49^{a}$ & $9.79 \pm 1.05^{\mathrm{a}}$ & $7.53 \pm 0.40^{\mathrm{a}}$ \\
\hline
\end{tabular}

*Within a column, means $( \pm \mathrm{SD}$ ) followed by same letter are not significantly different at $p<0.05$ according to Duncan multiple range test following analysis of variance (ANOVA) 


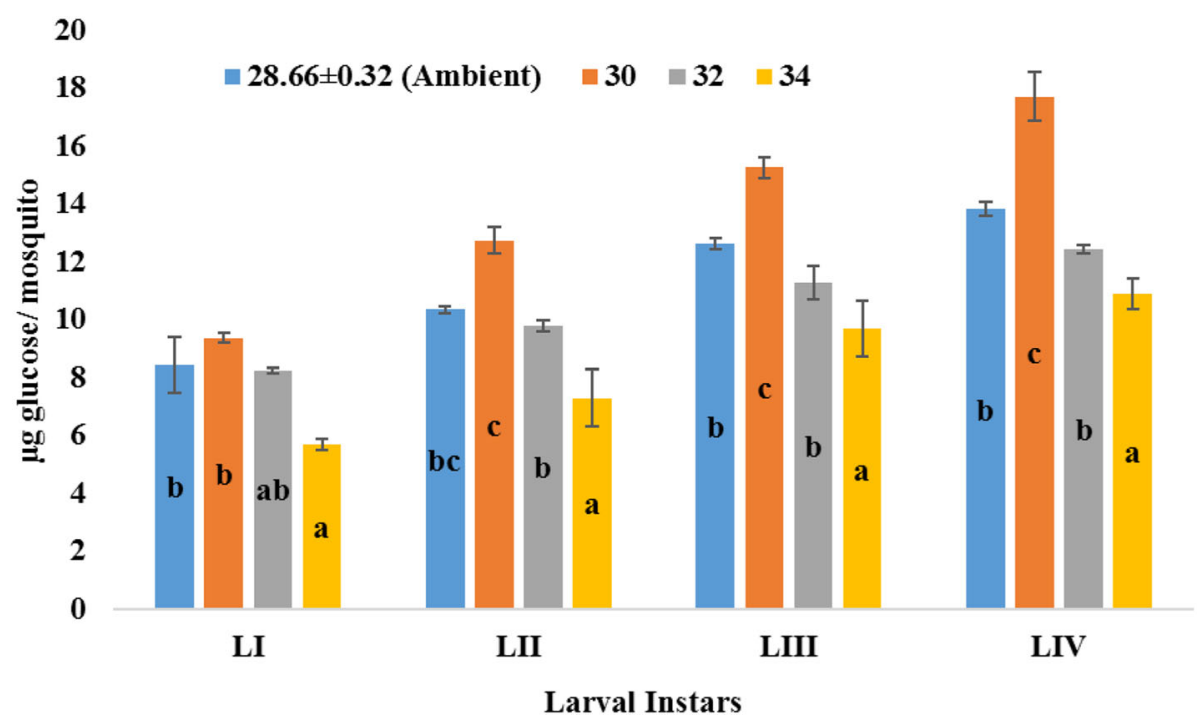

Fig. 5 Effects of rearing-water temperature on teneral glucose accumulation across larval instars (LI-IV) of Culex quinquefasciatus mosquito. Temperature bars with same letter at each larval instar are not significantly different at $p<0.05$ according to analysis of variance. Values are expressed as mean \pm SD

Effects of rearing-water temperature on larval rates of teneral reserve accumulation in Culex quinquefasciatus mosquito

The rate of accumulation of teneral reserves during the larval instar stages varied significantly $(p<0.05)$ with increase in temperature and teneral component type. Glycogen $(5.42 \pm 0.06$ to $6.99 \pm 0.11 \mu \mathrm{g} / \mathrm{mosquito} /$ day $)$ had the highest rate, while glucose had the lowest $(1.62$ \pm 0.02 to $2.52 \pm 0.16 \mu \mathrm{g} / \mathrm{mosquito} /$ day) (Table 7 ).

Effects of rearing-water temperature on metabolic reserve utilised during pupation and eclosion in Culex

\section{quinquefasciatus mosquito}

The quantities of lipid, protein, glucose and glycogen utilised for pupation varied significantly $(p<0.05)$ with temperature change. The total reserves utilised for pupation ranged from $20.30 \pm 9.89$ to $29.09 \pm 2.26 \mu \mathrm{g} /$ larva. The individual teneral utilised for pupation were similarly influenced by water temperature change (Table 8 ).
Metabolic reserve for eclosion of the species varied significantly $(p<0.05)$ among pupae in the various temperature regimens. Total reserve utilised ranged from $7.61 \pm 4.17 \mu \mathrm{g} /$ pupae (at $30{ }^{\circ} \mathrm{C}$ ) to $10.00 \pm 1.82 \mu \mathrm{g} /$ pupae (at $28.66 \pm 0.32{ }^{\circ} \mathrm{C}$ ). However, the quantities utilised at higher temperatures of 32 and $34.00{ }^{\circ} \mathrm{C}$ did not vary significantly (Table 9).

\section{Discussion}

Effects of rearing-water temperature on duration of development and growth rate of larval stages of Culex quinquefasciatus mosquito

The present study attempts to put into clearer perspective, developmental feats that could be exhibited by the vector species, $C x$. quinquefasciatus mosquito, in conditions where developmental temperatures of breeding habits peak as high as $34.00{ }^{\circ} \mathrm{C}$. Although, in the tropics, especially, in the study area and areas with similar ecotype, field studies suggest that breeding-water temperatures are between 27 and $30{ }^{\circ} \mathrm{C}$ (Okogun, Anosike,

Table 4 Effects of rearing-water temperature on teneral glucose mobilisation among the life stages of Culex quinquefasciatus mosquito

\begin{tabular}{|c|c|c|c|c|}
\hline \multirow[t]{2}{*}{ Temperature $\left({ }^{\circ} \mathrm{C}\right)$} & \multicolumn{4}{|c|}{ Glucose accumulation ( $\mu \mathrm{g} / \mathrm{mosquito})$} \\
\hline & Average larval & Pupal & Average immature & Adult \\
\hline $28.66 \pm 0.32$ & $11.31 \pm 0.22^{c^{*}}$ & $12.58 \pm 0.37^{c}$ & $11.57 \pm 0.22^{c}$ & $9.61 \pm 0.15^{b}$ \\
\hline 30.00 & $13.78 \pm 0.27^{d}$ & $16.54 \pm 1.10^{d}$ & $14.33 \pm 0.44^{d}$ & $13.86 \pm 0.83^{c}$ \\
\hline 32.00 & $10.44 \pm 0.20^{b}$ & $11.59 \pm 0.48^{b}$ & $10.67 \pm 0.26^{b}$ & $8.82 \pm 0.31^{a}$ \\
\hline 34.00 & $8.40 \pm 0.46^{\mathrm{a}}$ & $8.85 \pm 0.58^{\mathrm{a}}$ & $8.49 \pm 0.44^{\mathrm{a}}$ & $7.45 \pm 0.87^{\mathrm{a}}$ \\
\hline
\end{tabular}

*Within a column, means ( \pm SD) followed by same letter are not significantly different at $p<0.05$ according to Duncan multiple range test following analysis of variance (ANOVA) 


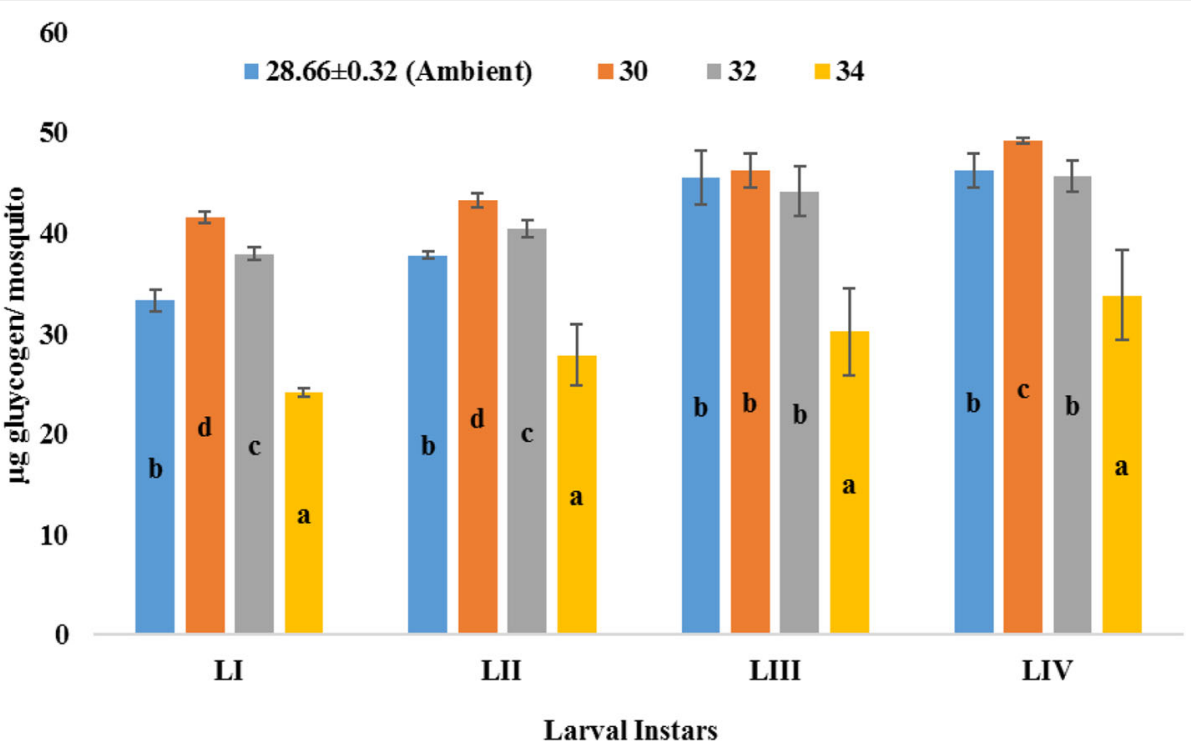

Fig. 6 Effects of rearing-water temperature on teneral glycogen accumulation across larval instars (LI-IV) of Culex quinquefasciatus mosquito. Temperature bars with same letter at each larval instar are not significantly different at $p<0.05$ according to analysis of variance. Values are expressed as mean $\pm \mathrm{SD}$

Okere, and Nwoke, 2005; Adebote, Oniyi, Ndams, and Nache, 2006; Mwangangi et al. 2007), and gravid females of $C x$. quinquefasciatus actively avoid habitats with temperatures above $30^{\circ} \mathrm{C}$ during oviposition (Oyewole et al. 2009; Olayemi, Omalu, Famotele, Shegna, and Idris, 2010; Tiimub, Adu, and Obiri-Danso, 2012). Further, little is known of what could happen in conditions where, either nature (through climate change) or man (passively or actively) contribute to increase in temperatures of mosquito breeding habits to as high as $34.00{ }^{\circ} \mathrm{C}$ in these areas.

The results of the present study show that increase in rearing-water temperatures significantly reduce duration of development (i.e., faster development) of immature life stages. For example, fastest developmental rates were observed in mosquitoes reared at the highest temperature tested $\left(34.00{ }^{\circ} \mathrm{C}\right)$, while the slowest developmental rates were observed at ambient temperature. The reduced duration of development in the former may be due to increased metabolic rates, elicited by quicker attainment of threshold size for growth occasioned by faster accumulation of teneral materials (Briegel, 1990b). Similar interactions between temperature and development times also exist for other mosquito species (Rueda, Patel, Axtell, and Stinner, 1990; Ribeiro, Costa, Loeck, Vianna, and Silveira Jr., 2004; Loetti et al. 2008; Dodson, Kramer, and Rasgon, 2012).

Further, the present study revealed variations in developmental times among immature life stages (especially, among larval instars) within a temperature regimen and among temperature regimens. Larval stage IV (LIV) spent the longest time as instar among the immature life stages in all temperature regimens. This is a physiological adaptation for attainment of pupation-threshold size and maximisation of teneral reserve accumulation for metamorphosis and adult life traits (Timmermann and Briegel, 1999).

Among this life stage (LIV) and at all temperature treatments, those reared at $34.00{ }^{\circ} \mathrm{C}$ developed fastest. This feat, perhaps, could have been occasioned by quicker pupation-threshold size attainment in this category of LIV

Table 5 Effects of rearing-water temperature on teneral glycogen mobilisation across life stages of Culex quinquefasciatus mosquito

\begin{tabular}{|c|c|c|c|c|}
\hline \multirow[t]{2}{*}{ Temperature $\left({ }^{\circ} \mathrm{C}\right)$} & \multicolumn{4}{|c|}{ Glycogen composition ( $\mu \mathrm{g} /$ mosquito) } \\
\hline & Average larval & Pupal & Average immature & Adult \\
\hline $28.66 \pm 0.32$ & $40.74 \pm 0.46^{b^{*}}$ & $31.65 \pm 0.99^{c}$ & $38.92 \pm 0.22^{b}$ & $30.04 \pm 0.24^{b}$ \\
\hline 30.00 & $45.06 \pm 0.03^{d}$ & $34.12 \pm 0.51^{d}$ & $42.87 \pm 0.12^{d}$ & $33.64 \pm 0.79^{c}$ \\
\hline 32.00 & $42.07 \pm 0.63^{c}$ & $29.94 \pm 1.37^{b}$ & $39.65 \pm 0.49^{c}$ & $29.52 \pm 0.55^{b}$ \\
\hline 34.00 & $28.19 \pm 2.34^{\mathrm{a}}$ & $24.95 \pm 0.71^{\mathrm{a}}$ & $28.19 \pm 2.34^{\mathrm{a}}$ & $22.63 \pm 0.85^{a}$ \\
\hline
\end{tabular}

*Within a column, means ( \pm SD) followed by same letter are not significantly different at $p<0.05$ according to Duncan multiple range test following analysis of variance (ANOVA) 


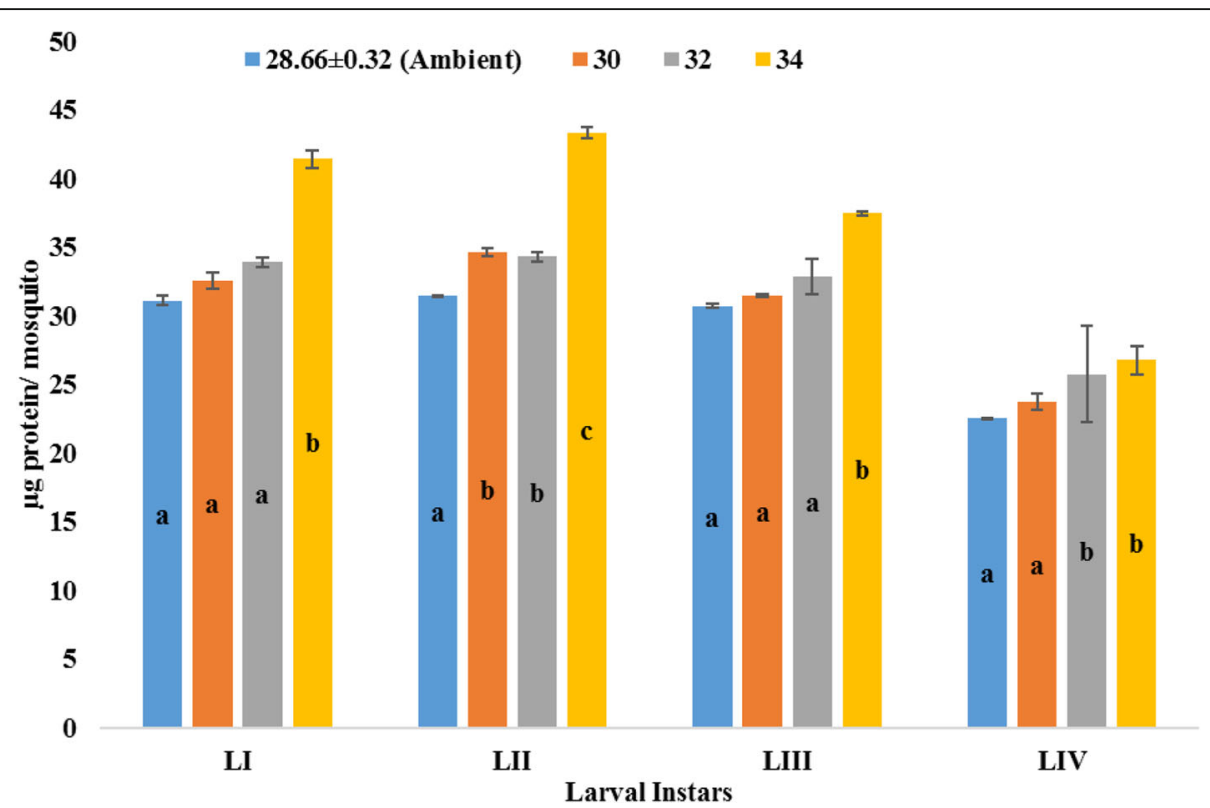

Fig. 7 Effects of rearing-water temperature on teneral protein accumulation across larval instars (LI-IV) of Culex quinquefasciatus mosquito. Temperature bars with same letter at each larval instar are not significantly different at $p<0.05$ according to analysis of variance. Values are expressed as mean $\pm \mathrm{SD}$

mosquitoes (Timmermann and Briegel, 1998) predicated by increased higher metabolic rates due to this temperature (Vinogradova and Karpova, 2006).

According to Timmermann and Briegel (1993), in mosquitoes, larval growth rates (LGR) are proxies for rates of metabolism: with higher values indicative of higher metabolic processes. In the present study, LGR, unlike duration of immature development, showed direct linear relationships with water temperature. The highest LGR value was obtained at $34.00{ }^{\circ} \mathrm{C}$, indicative that mosquitoes reared at this temperature have an increased metabolism, and may account for the fastest development observed for this cohort in this study.

Further, it suggests that mosquitoes reared at high temperatures (especially, within thermal limits) will have higher rates of metabolism, with faster growth rates (Bayoh and Lindsay, 2003). The study also revealed that, perhaps, significant increase in the temperature of natural habitats of this mosquito species (due to warmer climates or anthropogenic activities) could reduce developmental times; triggering adult mosquito population explosion, increased vector-human contacts, human-biting rates, with its attendant disease transmission.

\section{Effects of rearing-water temperature on survivorship of immature Culex quinquefasciatus mosquito}

The results of this study revealed that increasing rearing-water temperature has significant influence on survivorship of immature stages of $C x$. quinquefasciatus mosquito. For example, increased water temperature resulted in increased juvenile mortality, especially at $34.00{ }^{\circ} \mathrm{C}$. Surprisingly, this effect was most obvious at the final larval instars (LIV) than any other larval instar (LI-III) or pupal life stage. Earlier studies have suggested that this life stage (LIV) is the most resilient and physiologically stable immature life stage (World Health Organization, WHO, 1992). So, it was expected that this life stage should be better adapted to withstand the

Table 6 Effects of rearing-water temperature on teneral protein mobilisation of Culex quinquefasciatus mosquito

\begin{tabular}{|c|c|c|c|c|}
\hline \multirow[t]{2}{*}{ Temperature $\left({ }^{\circ} \mathrm{C}\right)$} & \multicolumn{4}{|c|}{ Protein accumulation ( $\mu \mathrm{g} / \mathrm{mosquito})$} \\
\hline & Average larval & Pupal & Average immature & Adult \\
\hline $28.66 \pm 0.32$ & $34.75 \pm 0.18^{c^{*}}$ & $31.56 \pm 0.30^{c}$ & $34.11 \pm 0.18^{c}$ & $29.36 \pm 0.13^{c}$ \\
\hline 30.00 & $35.93 \pm 0.18^{d}$ & $34.02 \pm 0.66^{d}$ & $35.55 \pm 0.15^{d}$ & $31.45 \pm 1.40^{d}$ \\
\hline 32.00 & $33.15 \pm 0.51^{c}$ & $28.40 \pm 0.17^{b}$ & $32.20 \pm 0.38^{b}$ & $25.04 \pm 0.07^{b}$ \\
\hline 34.00 & $24.70 \pm 0.96^{\mathrm{a}}$ & $21.77 \pm 1.96^{\mathrm{a}}$ & $24.11 \pm 0.71^{\mathrm{a}}$ & $17.81 \pm 1.02^{\mathrm{a}}$ \\
\hline
\end{tabular}

*Within a column, means ( \pm SD) followed by small letter are not significantly different at $p<0.05$ according to Duncan multiple range test following analysis of variance (ANOVA) 
Table 7 Effects of rearing-water temperature on accumulation rates of teneral reserve in Culex quinquefasciatus mosquito

\begin{tabular}{|c|c|c|c|c|}
\hline \multirow{2}{*}{$\begin{array}{l}\text { Temperature } \\
\left({ }^{\circ} \mathrm{C}\right)\end{array}$} & \multicolumn{4}{|c|}{ Accumulation rates ( $\mu \mathrm{g} / \mathrm{mosquito} /$ day) } \\
\hline & Lipid & Glucose & Glycogen & Protein \\
\hline $28.66 \pm 0.32$ & $2.61 \pm 0.06^{B^{*}} a^{* *}$ & $1.62 \pm 0.02^{\mathrm{A}}$ & $5.42 \pm 0.06^{A}$ & $4.86 \pm 0.10^{\mathrm{A}} \mathrm{b}$ \\
\hline 30.00 & $3.56 \pm 0.08_{a}^{C}$ & $2.52 \pm 0.16_{a}^{C}$ & $6.99 \pm 0.11_{b}$ & $6.15 \pm 0.10^{c} b$ \\
\hline 00 & $2.85 \pm 0.01^{\mathrm{B}} \mathrm{a}$ & $1.84 \pm 0.05_{\mathrm{a}}^{\mathrm{B}}$ & $6.76 \pm 0.11_{b}$ & $5.55 \pm 0.01_{b}^{B}$ \\
\hline 1.00 & $2.19 \pm 0.46^{A}{ }_{a}$ & $1.80 \pm 0.11_{\mathrm{a}}^{\mathrm{B}}$ & $5.59 \pm 1.05_{b}^{B}$ & $4.42 \pm 0.41_{b}^{c}$ \\
\hline
\end{tabular}

*Within a column, means $( \pm$ SD) followed by same capital letter are not significantly different at $p<0.05$ according to Duncan multiple range test following analysis of variance (ANOVA). **Within a line, means ( \pm SD) followed by same small letter are not significantly different at $p<0.05$ according to Duncan multiple range test following ANOVA

increasing high temperatures; however, the result of the present study suggests the contrary.

This high mortality (of this life stage, LIV) elicited by high temperature could be direct reactions to peaked accumulation of heat-related stress responses acquired during earlier successive larval instars (Feder, Blair, and Figueras, 1997; Oda et al. 2002) which increases chances of mortality (Parsons, 1989; Daly, Doyen, and Alexander, 1998). This finding, however, does not imply that this life stage (LIV) is not resilient/and or physiologically stable as earlier studies have shown, but may depict the effects of thermal stress on the life stage.

According to Karan and David (2000), for effective growth, insects must develop within temperature ranges, above which, enzymatic activities are seriously impaired, with possible death occurrence, and below which, developmental processes are reduced. The present study suggests a temperature threshold for effective development as $30.00{ }^{\circ} \mathrm{C}$; and may explain the significant increase in mortality as temperature increased above this.

Unlike the larval stage, pupal stage exhibited significant thermal resistance. This was not new, as earlier studies reported significantly higher adaptability of pupal stage to higher temperatures (Hoskins, 1932; Olayemi et al. 2016). This may be due to the possession of tougher integument by the pupal stage (Davis, 1932; Christophers, 1960). More so, this life stage (pupae) does not ecdyse: a process that leads to the production of thin, vulnerable cuticle that is easily damaged by high temperatures (Bowler, 1987). This finding is important, as despite the reported thermotolerance of this mosquito life stage (pupa), the present study suggests that a limit of thermal resistance may exist for it and may be in the range of $34.00{ }^{\circ} \mathrm{C}$.

The study further revealed that different temperature regimens support the species' immature duration of development and survivorship. For example, temperature of $34.00{ }^{\circ} \mathrm{C}$ was ideal for duration of development, as it supported fastest development, while temperatures of 30.00 and $32.00{ }^{\circ} \mathrm{C}$ supported maximum survivorship. It was further noted that the developmental temperature (of $34.00{ }^{\circ} \mathrm{C}$ ) which stimulated faster development elicited higher juvenile mortality. This may be suggestive that as regards temperature, other secondary factors, perhaps endogenous, e.g. synthesis of heat-resistant proteins and stress (Gehring and Wehner, 1995; Mpho, Callaghan, and Holloway, 2002b), may play greater roles in the development and survivorship of immature mosquitoes.

\section{Effects of rearing-water temperature on emergence, post- emergence longevity and daily survivorship and of adult life stage of Culex quinquefasciatus mosquito}

The result of this study revealed that increasing water temperature had significant effects on total number of emergent mosquitoes, especially, on the numbers of male and female adult mosquitoes. For example, as temperature progressively increased from ambient to $34.00{ }^{\circ} \mathrm{C}$, the total number of adult that emerged, significantly, reduced. This phenomenon suggests reduction in rate of eclosion with increase in temperature. Earlier, Alto and Juliano (2001) have reported similar observations in Aedes mosquito.

The result of this study also showed was skewness of sex towards female of the species, as greater numbers of female adult mosquitoes emerged more than their counterpart male at all temperature regimen. Could this be the norm in mosquito development and reproduction or connote greater thermotolerance by female pupae than their male counterparts?

Table 8 Effects of rearing-water temperature on metabolic reserve for pupation in Culex quinquefasciatus mosquito

\begin{tabular}{|c|c|c|c|c|c|}
\hline \multirow[t]{2}{*}{ Temperature $\left({ }^{\circ} \mathrm{C}\right)$} & \multicolumn{4}{|c|}{ Teneral reserve component ( $\mu \mathrm{g} /$ larva) } & \multirow{2}{*}{ 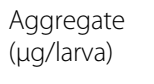 } \\
\hline & Lipid & Protein & Glucose & Glycogen & \\
\hline $28.66 \pm 0.32$ & $3.29 \pm 0.26^{A^{*}} b^{* *}$ & $9.89 \pm 0.36^{D_{C}}$ & $14.63 \pm 1.36_{d}^{B}$ & $1.25 \pm 0.28^{B}{ }_{a}$ & $29.06 \pm 2.26^{B}$ \\
\hline 30.00 & $3.02 \pm 0.12^{B} b$ & $9.31 \pm 0.35^{C_{c}}$ & $15.09 \pm 0.70_{d}^{C}$ & $1.17 \pm 0.25^{\mathrm{AB}}{ }_{\mathrm{a}}$ & $28.59 \pm 1.42^{B}$ \\
\hline 32.00 & $2.30 \pm 0.03^{A} b$ & $9.10 \pm 0.73_{c}^{B}$ & $15.75 \pm 0.18^{D}$ & $0.84 \pm 0.32^{\mathrm{A}} \mathrm{a}$ & $27.99 \pm 1.26^{B}$ \\
\hline 34.00 & $4.37 \pm 2.06_{b}^{C}$ & $5.02 \pm 2.28^{\mathrm{A}}{ }_{\mathrm{C}}$ & $8.84 \pm 4.92_{d}^{A}$ & $2.07 \pm 0.63^{C} a$ & $20.30 \pm 9.89^{A}$ \\
\hline
\end{tabular}

*Within a column, means ( \pm SD) followed by same capital letter are not significantly different at $p<0.05$ according to Duncan multiple range test following analysis of variance (ANOVA). **Within a line, means $( \pm S D)$ followed by same small letter are not significantly different at $p<0.05$ according to Duncan multiple range test following ANOVA 
Table 9 Effects of Rearing-water Temperature on Metabolic Reserve utilised for Eclosion in Culex quinquefasciatus mosquito

\begin{tabular}{|c|c|c|c|c|c|}
\hline \multirow[t]{2}{*}{ Temperature $\left({ }^{\circ} \mathrm{C}\right)$} & \multicolumn{4}{|c|}{ Teneral reserve component ( $\mu \mathrm{g} / \mathrm{pupa})$} & \multirow{2}{*}{$\begin{array}{l}\text { Aggregate } \\
\text { ( } \mu \mathrm{g} / \text { pupa }\end{array}$} \\
\hline & Lipid & Protein & Glucose & Glycogen & \\
\hline $28.66 \pm 0.32$ & $3.24 \pm 0.36^{C^{*}}{ }_{d^{* *}}$ & $2.19 \pm 0.17_{b}^{A}$ & $1.60 \pm 0.86_{a}^{C}$ & $2.97 \pm 0.43_{c}^{B}$ & $10.00 \pm 1.82$ \\
\hline 30.00 & $1.36 \pm 0.55^{\mathrm{A}} \mathrm{b}$ & $2.56 \pm 1.33^{\mathrm{AB}}{ }_{c}$ & $1.01 \pm 0.67_{a}^{\mathrm{A}}$ & $2.68 \pm 1.62_{d}^{B}$ & $7.61 \pm 4.17^{\mathrm{A}}$ \\
\hline 32.00 & $2.19 \pm 0.95^{B} b$ & $3.36 \pm 0.22_{c}^{B}$ & $1.44 \pm 0.90^{\mathrm{B}} \mathrm{a}$ & $2.22 \pm 0.64^{B} b$ & $9.21 \pm 2.71^{B}$ \\
\hline 34.00 & $1.34 \pm 0.51^{\mathrm{A}}{ }_{\mathrm{a}}$ & $3.96 \pm 2.13_{c}^{C}$ & $2.31 \pm 0.75^{d} b$ & $1.40 \pm 1.20^{\mathrm{B}}{ }_{\mathrm{a}}$ & $9.01 \pm 4.59^{B}$ \\
\hline
\end{tabular}

*Within a column, means $( \pm \mathrm{SD})$ followed by same capital letter are not significantly different at $p<0.05$ according to Duncan multiple range test following analysis of variance (ANOVA). **Within a line, means $( \pm \mathrm{SD})$ followed by same small letter are not significantly different at $p<0.05$ according to Duncan multiple range test following ANOVA

Post-emergence longevity was negatively affected by increase in temperature, as mosquitoes reared at $34.00^{\circ}$ C were the shortest-lived. Earlier, Reisen (1995) had reported that thermal stress significantly reduced longevity in Culex tarsalis. This may imply that as temperature of immature mosquito-breeding habitats increase, there may be a reduction in pathogen transmission tendencies, occasioned by the ephemeral nature of emergent adults from high temperature. These mosquitoes may not live long enough to ensure complete development of the pathogen within the vector.

In the present study, it is worthy of note that female mosquitoes from all temperature regimens lived longer than their male counterparts. Perhaps, indicative of possible greater endowment by nature on female mosquitoes to live longer for continuity of life and for cyclical transmission of pathogens of diseases (Pelizza, López Lastra, Becnel, Bisaro, and García, 2007).

Rearing-water temperature also affected daily adult survivorship of the mosquito species $(>60.00 \%$ for all temperature regimens). Adults from ambient temperature had the highest survivorship, while those from $34.00{ }^{\circ} \mathrm{C}$, the least. This is in tandem with the reports of Loetti, Burroni, Schweigmann, and de Garin (2007) and Mpho et al. (2002a, 2002b); who reported decreased adult survival rates with increase in temperature.

Comparison of survivorship among and between sexes of the species revealed that male and female mosquitoes from ambient temperature survived most, though the values recorded at this temperature for the sexes were not significantly different from those at 30 and $32.00{ }^{\circ} \mathrm{C}$. Further, there was no significant difference in the daily survivorship between sexes, i.e. male and female from a particular temperature regimen. The reason for this was not clear, but, perhaps, indicative of indifference in effects of a particular temperature regimen on survivorship of adult mosquitoes.

\section{Effects of rearing-water temperature on life stages' accumulation of teneral reserves in Culex quinquefasciatus mosquito}

In the present study, teneral reserve composition of the species exhibited an inverse relationship with temperature, i.e. their relative composition reduced, significantly, as temperature increased. The quantities of each teneral component also, significantly, reduced with increase in temperature.

According to Bochdanovits and De Jong (2003), the quantity of teneral reserves (i.e., lipid, protein, sugar and glycogen) acquired during immature phago-stage determines most adult vectorial fitness attributes. This, however, is the case in most anautogenous mosquitoes (e.g. Cx. quinquefasciatus) and few autogenous species. In mosquitoes, teneral reserves are major determinant of initial host seeking tendencies (Campbell, Thiemann, Lemenager, and Reisen, 2013), duration before initial blood meal intake (Nasci, 1986), egg development (Hooper, Sibly, Hutchinson, and Maud, 2003), adult longevity (Hawley, 1985), and general quality of adult life (Klowden, Blackmer, and Chambers, 1988).

In the present study, irrespective of temperature regimen, there was a general increase in teneral reserve accumulation in the larval instars (LI-IV). This was followed by gradual decrease in composition as the life stage progressed through the pupal and adult life stages. These latter reductions may represent physiological utilisation of teneral components for general reconstruction and development of vital organs/structures at pupal stage and eclosion processes for adult. It, therefore, follows that conditions that increase demand on utilisation of teneral components for pupation and eclosion will, ultimately, reduce the quantity of teneral available for adult life. This will, no doubt, affect vectorial fitness, hence, disease-vector reduction.

Also, mosquitoes reared at $34.00{ }^{\circ} \mathrm{C}$ had the least teneral component accumulations. For example, mosquito reared at this temperature had the least protein contents, perhaps, due to denaturing of protein proteins by heat. Meanwhile, this cohort recorded low lipid, glucose and glycogen contents. This, perhaps, indicate increased expenditure of stored-reserve for the heightened physical activities (elicited by the high temperature), coupled with the reduced feed intake (both due to thermal stress) by the mosquito. 


\section{Effects of rearing-water temperature on larval rates of teneral reserve accumulation in Culex quinquefasciatus mosquito}

Daily larval rates of teneral accumulation were highest at $30.00{ }^{\circ} \mathrm{C}$ and lowest at $34.00{ }^{\circ} \mathrm{C}$. These differences could be partly responsible for results obtained for most of the entomological parameters determined in the present study at these temperatures. Higher rates of teneral accumulation support greater developmental fitness indices (Timmermann and Briegel, 1999). Among the teneral components, glycogen and protein had highest values at all temperature tested. This may signify greater importance of these two in structure formation and energy storage (Gillott, 2005).

\section{Effects of rearing-water temperature on metabolic reserve for pupation and eclosion of Culex quinquefasciatus mosquito}

The quantity and quality of teneral reserve acquired during the last larval instar (LIV), determines the metabolic reserve available for metamorphosis (i.e. pupation and eclosion) (Briegel, 2003). It also determines the quality of adults produced at eclosion (Hawley, 1985).

In the present study, disparity was observed in the quantity of reserves utilised for these metamorphic processes (i.e. pupation and eclosion). For example, different quantities of and component type of teneral reserve were utilised by the mosquito species with increase in temperature. The mosquitoes reared at $34.00{ }^{\circ} \mathrm{C}$ utilised comparatively more quantities of lipid and glycogen than protein and sugar for pupation than they did at eclosion, relative to other mosquitoes from other temperatures. They also utilised relatively, the highest quantities of protein and sugar for eclosion; this have resulted in the emergence of adults with relatively low teneral reserve component. This observation is of epidemiological importance, as it may represent reduction in vectorial fitness and impairment of adult life attributes of these mosquitoes, especially, egg development propensities.

Finally, the mosquitoes reared at $30.00{ }^{\circ} \mathrm{C}$ expended moderately to low quantities of metabolic reserve for the metamorphic processes of pupation and eclosion. This has resulted in the emergence of adult mosquitoes with comparatively larger amount of teneral reserve components for adult life. Hence, this temperature regimen may be the threshold for development of this species. More so, there are greater tendencies of mosquitoes from this temperature regimen becoming more efficient in the cyclical transmission of pathogens of disease.

\section{Conclusions}

The present study revealed significant effects of increasing temperature on vectorial attribute indices investigated (i.e. duration of development, growth rates, survivorship, emergence, longevity, rates of teneral accumulation and utilisation. Among these, only larval growth rates increased with temperature increase, while other measured parameters were negatively affected. More so, temperature of $30.00{ }^{\circ} \mathrm{C}$ seems to favour more developmental and vectorial attributes of the mosquito species.

Further, the study also showed that a constant 2-degree rise in temperature can affect the physiology of the mosquito species and, hence, the vectorial fitness. Increasing immature rearing-water temperature, may lead to the emergence of mosquitoes, less fit to transmit disease pathogens. The information contained in this study is important in understanding the interplay between temperature and mosquito development, for the development of temperature-based control protocols and models for vector control.

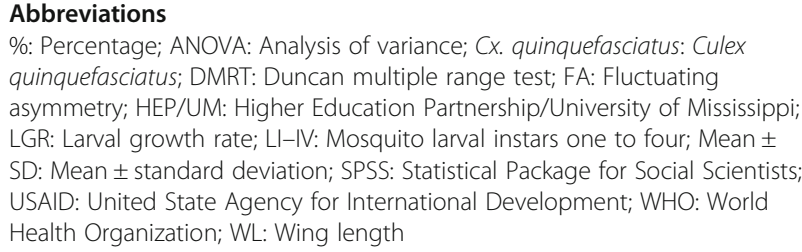

\section{Acknowledgements}

Our deepest appreciation goes to the Management of Federal University of Technology, Minna for facilitating the USAID/ HEP/UM grant. We also appreciate the Staff members of the Department of Biological Sciences, Federal University of Technology, Minna, especially, the Head of Laboratory, Mrs. J. O. Oluwafemi for providing a conducive environment for the study.

\section{Funding}

The funding sponsors (United State Agency for International Development (USAID), Higher Education Partnership/University of Mississippi (HEP/UM)) had no role in the design of the study; in the collection, analyses or interpretation of data; in the writing of the manuscript; and in the decision to publish the results.

Availability of data and materials

Data sharing not applicable to this article as no datasets were generated or analysed during the current study.

Authors' contributions

$A C U, I K O, F O A, I C J O$ and $M O O$ conceived and designed the experiments. $A C U, B M B, C C U$ and KAA performed the experiments. ACU, IKO, FOA, ICJO and KAA analysed the data. UAC and CCU wrote the first draft of the manuscript. IKO, FOA, ICJO and MOO corrected the draft copy. All authors agreed to the final state of the manuscript.

Ethics approval and consent to participate Not applicable.

\section{Consent for publication}

Not applicable.

Competing interests

The authors declare that they have no competing interests.

\section{Publisher's Note}

Springer Nature remains neutral with regard to jurisdictional claims in published maps and institutional affiliations. 


\section{Author details}

'Department of Animal Biology, Applied Entomology Unit, Federal University of Technology, Minna, Nigeria. 'Department of Animal Biology, Applied Hydrobiology Unit, Federal University of Technology, Minna, Nigeria. ${ }^{3}$ Department of Animal Biology, Applied Parasitology Unit, Federal University of Technology, Minna, Nigeria. ${ }^{4}$ Department of Water, Aquaculture and Fisheries Technology, Federal University of Technology, Minna, Nigeria. ${ }^{5}$ Department of Microbiology, Federal University of Technology, Minna, Nigeria.

\section{Received: 14 March 2018 Accepted: 18 July 2018}

Published online: 10 August 2018

\section{References}

Adebote, D. A., Oniyi, S. J., Ndams, I. S., \& Nache, K. M. (2006). The breeding of mosquitoes in peri-domestic containers and implication in yellow fever transmission in villages around Zaria, Northern Nigeria. Journal of Entomology, 3(2), 180-188.

Al-Saffar, Z. Y., Grainger, J. N. R., \& Aldrich, J. (1995). Influence of constant and changing temperature and humidity on the development and survival of the eggs and pupae of Drosophila melanogaster (Meigen). Journal of Thermal Biology, 20, 389-397.

Alto, B. W., \& Juliano, S. A. (2001). Temperature effects on the dynamics of Aedes albopictus (Diptera: Culicidae) populations in the laboratory. Journal of Medical Entomology, 38, 548-556.

Armbruster, P., \& Hutchinson, R. A. (2002). Pupal mass and wing length as indicators of fecundity in Aedes albopictus and Aedes geniculatus (Diptera: Culicidae). Journal of Medical Entomology, 39, 699-704.

Atkinson, D. (1995). Effects of temperature on the size of aquatic ectotherms: Exceptions to the general rule. Journal of Thermal Biology, 20, 61-74.

Bayoh, M. N., \& Lindsay, S. W. (2003). Effect of temperature on the development of the aquatic stages of Anopheles gambiae sensu stricto (Diptera: Culicidae). Bulletin of Entomology Research, 93, 375-381.

Bochdanovits, Z., \& De Jong, G. (2003). Temperature dependent larval resource allocation shaping adult body size in Drosophila melanogaster. Journal of Evolutionary Biology, 16, 1159-1167.

Bowler, K. (1987). Cellular heat injury. Are membranes involved? In K. Bowler, \& B. J. Fuller (Eds.), Temperature and animal cells, (pp. 157-185). Cambridge: Society of Experimental Biology Symposium.

Briegel, H. (1990a). Metabolic relationship between female body size, reserves, and fecundity of Aedes aegypti. Journal of Insect Physiology, 36, 165-172.

Briegel, H. (1990b). Fecundity, metabolism, and body size in Anopheles (Diptera: Culicidae), vectors of malaria. Journal of Medical Entomology, 27, 839-850.

Briegel, H. (2003). Physiological bases of mosquito ecology. Journal of Vector Ecology, 28, 1-11.

Campbell, R., Thiemann, T. C., Lemenager, D., \& Reisen, W. K. (2013). Hostselection patterns of Culex tarsalis (Diptera: Culicidae) determine the spatial heterogeneity of West Nile virus enzootic activity in Northern California. Journal of Medical Entomology, 50(6), 1303-1309.

Carrington, L. B., Armijos, M. V., Lambrechts, L., Barker, C. M., \& Scott, T. W. (2013). Effects of fluctuating daily temperatures at critical thermal extremes on Aedes aegypti life-history traits. PLoS One, 8(3), e58824. https://doi.org/10.1371/ journal.pone.0058824.

Christophers, S. R. (1960). Aedes aegypti (L.) the yellow fever mosquito: Its life history, bionomics and structure, (p. 750). London: Cambridge University Press.

Daly, H. V., Doyen, J. T., \& Alexander, H. P. (1998). Introduction to insect biology and diversity, (2nd ed., p. 137). New York: Oxford University Press.

Davis, N. C. (1932). The effect of heat and cold upon Aedes (Stegomyia) aegypti. American Journal of Hygiene, 16, 177-191.

Dodson, B. L., Kramer, L. D., \& Rasgon, J. L. (2012). Effects of larval rearing temperature on immature development and West Nile virus vector competence of Culex tarsalis. Parasites and Vectors, 5, 199.

Feder, M. E., Blair, N., \& Figueras, H. (1997). Natural thermal stress and heat-shock protein expression in Drosophila larvae and pupae. Functional Ecology, 11, 90-100.

Gehring, W. J., \& Wehner, R. (1995). Heat-shock protein-synthesis and thermotolerance in Cataglyphis an ant from the Sahara Desert. Proceedings of the National Academy of Sciences of the United States of America, 92, 2994-2998.

Gillott, C. (2005). Entomology, (3rd ed., pp. 500-511). Dordrecht: Springer Publishing.

Hawley, W. A. (1985). The effect of larval density on adult longevity of a mosquito, Aedes sierrensis: Epidemiological consequences. Journal of Animal Ecology, 54, 955-964.
Hooper, H. L., Sibly, R. M., Hutchinson, T. H., \& Maud, S. J. (2003). The influence of larval density, food availability and habitat longevity on the life history and population growth rate of the midge Chironomus riparius. Oikos, 102, 515-524.

Hoskins, W. M. (1932). Toxicity and permeability. I. The toxicity of acid and basic solutions of Sodium arsenite to mosquito pupae. Journal of Economic Entomology, 25, 1212-1224.

Joshi, D. (1996). Effect of fluctuating and constant temperatures on development, adult longevity and fecundity in the mosquito Aedes krombeini. Journal of Thermal Biology, 21, 151-154.

Karan, D., \& David, J. R. (2000). Cold tolerance in Drosophila: adaptive variations revealed by the analysis of starvation survival reaction norms. Journal of Thermal Biology, 25, 345-351.

Kaufmann, C., Brown, M.R., (2008). Regulation of carbohydrate metabolism and flight performance by a hypertrehalosaemic hormone in the mosquito Anopheles gambiae. Journal of Insect Physiology, 54, 367-377.

Klowden, M. J., Blackmer, J. L., \& Chambers, G. M. (1988). Effects of larval nutrition on the host-seeking behaviour of adult Aedes aegypti mosquitoes. Journal of America Mosquito Control Association, 4, 73-75.

Lanciani, C. A., \& Le, T. M. (1995). Effect of temperature on the wing length-body weight relationship in Anopheles quadrimaculatus. Journal of American Mosquito Control Association, 11, 241-243.

Loetti, M. V., Burroni, N. E., Schweigmann, N., \& de Garin, A. (2007). Effect of different thermal conditions on the pre-imaginal biology of Culex apicinus (Philippi, 1865) (Diptera: Culicidae). Journal of Vector Ecology, 32, 106.

Loetti, M. V., Nora, E. B., Paula, P., \& Schweigmann, N. (2008). Effect of temperature on the development time and survival of preimaginal Culex hepperi (Diptera: Culicidae). Revolutionary Society of Entomology, 67(3-4), 79-85.

Loetti, V., Nicolás, S., \& Burronia, N. (2011). Development rates, larval survivorship and wing length of Culex pipiens (Diptera: Culicidae) at constant temperatures. Journal of Natural History, 45(35-36), 2207-2217.

Markow, T. A. (1995). Evolutionary ecology and developmental stability. Annual Reviews in Entomology, 7, 328-332.

Mourya, D. T., Yadav, P., \& Mishra, A. C. (2004). Effect of temperature stress on immature stages and susceptibility of Aedes aegypti mosquitoes to chikungunya virus. American Journal of Tropical Medicine and Hygiene, 70, 346-350.

Mpho, M., Callaghan, A., \& Holloway, G. J. (2002b). Effects of temperature and genetic stress on life history and fluctuating wing asymmetry in Culex pipiens mosquitoes. European Journal of Entomology, 99, 405-412.

Mpho, M., Callaghan, A., \& Holloway, G. R. (2002a). Temperature and genotypic effects on life history and fluctuating asymmetry in a field strain of Culex pipiens. Heredity, 88, 307-312.

Mwangangi, J. M., Mbogo, C. M., Muturi, E. J., Nzovu, J. G., Kabiru, E. W., Githure, J. I., ... Beier, J. C. (2007). Influence of biological and physicochemical characteristics of larval habitats on the body size of Anopheles gambiae mosquitoes (Diptera: Culicidae) along the Kenyan coast. Journal of Vector Borne Diseases, 44, 122-127.

Nasci, R. S. (1986). The size of emerging and host-seeking Aedes aegypti and the relation of size to blood feeding success in the field. Journal of the American Mosquito Control Association, 2(1), 61-62.

Nasci, R. S., Berry, R. L., Restifo, R. A., \& Moore, C. G. (1996). Population size, parity structure, and wing length of Coquillettidia perturbans in an Ohio focus of eastern equine encephalitis. Journal of American Mosquito Control Association, 12, 64-68.

Oda, T., Eshita, Y., Uchida, K., Mine, M., Eshita, Y., Kurokawa, K., ... Tahara, H. (2002). Reproductive activity and survival of Culex pipiens pallens and Culex quinquefasciatus (Diptera: Culicidae) in Japan at high temperature. Journal of Medical Entomology, 39, 185-190.

Okogun, G. R. A., Anosike, J. C., Okere, A. N., \& Nwoke, B. E. B. (2005). Ecology of Mosquitoes of Midwestern Nigeria. Journal of Vector Borne Diseases, 42, 1-8.

Olayemi, I. K., \& Ande, A. T. (2009). Life table analysis of Anopheles gambiae (Diptera: Culicidae) in relation to malaria transmission. Journal of Vector-Borne Diseases, 46, 295-298.

Olayemi, I. K., Omalu, I. C. J., Famotele, O. I., Shegna, S. P., \& Idris, B. (2010). Distribution of mosquito larvae in relation to physico-chemical characteristics of breeding habitats in Minna, North Central Nigeria. Reviews in Infection, 1(1), 49-53.

Olayemi, I. K., Onumanyi, V., Ukubuiwe, A. C., \& Jibrin, A. I. (2016). Effects of Temperature Stress on Pre-imaginal Development and Adult Ptero-fitness of the Vector Mosquito, Culex quinquefasciatus (Diptera: Culicidae). Journal of Mosquito Research, 6(14), 1-7. https://doi.org/10.5376/jmr.2016.06.0014. 
Oyewole, I. O., Momoh, O. O., Anyasor, G. N., Ogunnowo, A. A., Ibidapo, C. A., Oduola, O. A., ... Awolola, T. S. (2009). Physico-chemical characteristics of Anopheles breeding sites: Impact on fecundity and progeny development. African Journal of Environmental Science and Technology, 3(12), 447-452.

Parsons, P. A. (1989). Environmental stresses and conservation of natural populations. Annual Reviews on Ecology and Systems, 20, 29-49.

Parsons, P. A. (1990). Fluctuating asymmetry: An epigenetic measure of stress. Biological Reviews, 65, 131-145.

Pelizza, S. A., López Lastra, C. C., Becnel, J. J., Bisaro, V., \& García, J. J. (2007). Effects of temperature, $\mathrm{pH}$ and salinity on the infection of Leptolegnia chapmanil Seymour (Peronosporomycetes) in mosquito larvae. Journal of Invertebrate Pathology, 96, 133-137.

Phasomkusolsil, S., Lerdthusnee, K., Khuntirat, B., Kongtak, W., Pantuwatana, K., \& Murphy, J. R. (2011). Effect of temperature on laboratory reared Anopheles dirus Peyton and Harrison and Anopheles sawadwongporni Rattanarithikul and Green. Southeast Asian Journal of Tropical Medicine and Public Health, 42(1), 63-70.

Randell, H. F., Dickinson, K. L., Shayo, E. H., Mboera, L. E. G., \& Kramer, R. A. (2010). Environmental management for malaria control: Knowledge and practices in Mvomero, Tanzania. EcoHealth, 7(4), 507-516.

Reisen, W. K. (1995). Effect of temperature on Culex tarsalis (Diptera: Culicidae) from the Coachella and San Joaquin Valleys of California. Journal of Medical Entomology, 32, 636-645.

Ribeiro, P. B., Costa, P. R. P., Loeck, A. E., Vianna, E. E. S., \& Silveira Jr., P. (2004). Exigências térmicas de Culex quinquefasciatus (Diptera, Culicidae) em Pelotas, Rio Grande do Sul, Brasil. Iheringia, Série Zoologica, 94, 177-180.

Rueda, L. M., Patel, K. J., Axtell, R. C., \& Stinner, R. E. (1990). Temperaturedependent development and survival rates of Culex quinquefasciatus and Aedes aegypti (Diptera: Culicidae). Journal of Medical Entomology, 27, 892-898.

Sibly, R. M., \& Atkinson, D. (1994). How rearing temperature affects optimal adult size in ectotherms. Functional Ecology, 8, 486-493.

Strickman, D., \& Kittayapong, P. (2003). Dengue and its vectors in Thailand: Calculated transmission risk from total pupal counts of Aedes aegypti and association of wing-length measurements with aspects of the larval habitat. American Journal of Tropical Medicine and Hygiene, 68, 209-217.

Tiimub, B. M., Adu, B. K., \& Obiri-Danso, K. (2012). Physico-chemical assessment of mosquito breeding sites from selected mining communities at the Obuasi Municipality in Ghana. Journal of Environment and Earth Science, 2(10), 123-129.

Timmermann, S. E., \& Briegel, H. (1993). Water depth and larval density affect development and accumulation of reserves in laboratory populations of mosquitoes. Bulletin of the Society of Vector Ecology, 18, 174-187.

Timmermann, S. E., \& Briegel, H. (1998). Moulting and metamorphosis in mosquito larvae: A morphometric analysis. Mittheilungen der Schweizerischen Entomologischen Gesellschaft, 71, 373-387.

Timmermann, S. E., \& Briegel, H. (1999). Larval growth and biosynthesis of reserves in mosquitoes. Journal of Insect Physiology, 45, 461-470.

Ukubuiwe, AC., \& Olayemi, IK. (2014). Effects of temperature stress on the morphometrics of immature and imagoes of the Culex pipiens pipiens (Diptera: Culicidae) Mosquito population, a Principal Vector of Filariasis in Minna, North Central Nigeria. Paper presented at the 45th Annual Conference of the Entomological Society of Nigeria (ESN), Held at the University of Abuja, Abuja, from 7- 10th October, 2014.

Ukubuiwe, A. C., Olayemi, I. K., \& Jibrin, A. I. (2016). Genetic variations in bionomics of Culex quinquefasciatus (Diptera: Culicidae) mosquito population in Minna, North Central Nigeria. International Journal of Insect Science, 8, 1-7.

Ukubuiwe, A. C., Olayemi, I. K., Omalu, I. C. J., Arimoro, F. O., Salihu, I. M., Jibrin, A. I., ... Yunusa, R. Y. (2017). Influence of photoperiod on larval growth indices and energy budget for metamorphosis in Culex quinquefasciatus mosquito (Diptera: Culicidae): its implication in integrated vector management, Proceedings from the $30^{\text {th }}$ International Conference of the Biotechnology Society of Nigeria (BSN), held at the Federal University of Technology, Minna from $27^{\text {th }}$ to $30^{\text {th }}$ August, 2017 (pp. 167-176).

Ukubuiwe, A. C., Olayemi, I. K., Omalu, I. C. J., Jibrin, A., \& Oyibo-Usman, K. (2013). Molecular bases of reproductive and vectorial fitness of Culex pipiens pipiens (Diptera: Culicidae) mosquito populations, for the transmission of filariasis in North Central Nigeria. Journal of Medical Sciences, 13(3), 201-201. JMS (ISSN 1682-4474)/https://doi.org/10.3923/jms.2013.201.207.

Van-Handel, E. (1985a). Rapid determination of glycogen and sugar in mosquitoes. Journal of the American Mosquito Control Association, 1, 299-304.

Van-Handel, E. (1985b). Rapid determination of total lipids in mosquitoes. Journal of the American Mosquito Control Association, 1, 302-304.
Van-Handel, E., \& Day, J. F. (1988). Assay of lipids, glycogen and sugars in individual mosquitoes: Correlations with wing length in field-collected Aedes vexans. Journal of the American Mosquito Control Association, 4, 549-550.

Vinogradova, E. B., \& Karpova, S. G. (2006). Effect of photoperiod and temperature on the autogeny rate, fecundity and wing length in the urban mosquito, Culex pipiens pipiens $f$. molestus (Diptera, Culicidae). International Journal of Dipteran Research, 17(1), 3-12.

Workman, P. D., \& Walton, W. E. (2000). Emergence patterns of Culex mosquitoes (Diptera: Culicidae) at an experimental constructed treatment wetland in southern California. Journal of the American Mosquito Control Association, 16, 124-130.

World Health Organization, WHO (1992). Vector Resistance to Pesticide. Fifteenth Report of the WHO Committee on Vector Biology and Control, (vol. 35, pp. 143-148).

\section{Submit your manuscript to a SpringerOpen ${ }^{\circ}$ journal and benefit from:}

- Convenient online submission

- Rigorous peer review

- Open access: articles freely available online

- High visibility within the field

- Retaining the copyright to your article

Submit your next manuscript at $\boldsymbol{\triangleright}$ springeropen.com 